\title{
Effect of forest fire on tree diversity and regeneration potential in a tropical dry deciduous forest of Mudumalai Tiger Reserve, Western Ghats, India
}

\author{
Satyam Verma, Dharmatma Singh, Sathya Mani and Shanmuganathan Jayakumar
}

\begin{abstract}
Introduction: The study was conducted in Mudumalai Tiger Reserve, in the Western Ghats to understand the effect of a single fire event on tree diversity and regeneration status. Four forest patches were selected which were unburned, 2-year-old burn, 5-year-old burn, and 15-year-old burn. Three 0.1 ha square plots were laid randomly in all four patches and analyzed for tree diversity, stand structure, and regeneration of tree species.

Results: A total of 4129 individuals of tree species were recorded in field surveys, comprising 3474 seedlings, 121 saplings, and 534 trees. Totally, 40 tree species were recorded in study plots, from which 28 species were seedlings, 16 species were saplings, and 37 species were at tree stages.

Conclusions: Tree diversity decreased in 2-year-old and 5-year-old burnt plots and was reached to the level of unburnt plots in 15 years of interval. Stems of small size classes started increasing after the fire. Seedling density increased linearly in subsequent years after fire but sapling and tree density recorded less than control in B2 but was higher in B5 and B15. The overall fire affected diversity, but regeneration showed a positive trend.
\end{abstract}

Keywords: Dry deciduous forest, Forest fire, Fire mapping, Regeneration, Western Ghats

\section{Introduction}

Fire is a significant ecological event that can produce variable effects (Keane et al. 2002, Whelan 1995). Forest fires strongly affect the species composition of plant communities (Danthu et al. 2003) by influencing different aspects of growth and development, like flowering, seed dispersal, germination, seedling establishment, and plant mortality (De Luis et al. 2005, Walters et al. 2004). Forest fires affect vegetation by suppressing certain species and encouraging other species causing changes in vegetation structure and successional pattern (Syaufina and Nuruddin 2011). Forest regeneration has been affected by fire through killing stem tissues of seedlings and saplings and heating the soil sufficiently to kill roots and

\footnotetext{
* Correspondence: jayakumar.eco@pondiuni.edu.in

Environmental Informatics and Spatial Modeling Lab, Department of Ecology and Environmental Sciences, School of Life Sciences, Pondicherry University, Puducherry 605 014, India
}

seeds near the soil surface (Balch et al. 2013, Kennard et al. 2002).

In tropical dry deciduous forests, where fires are very frequent, plants display some adaptive traits like thick bark, the capability of healing fire scars, seed adaptations, and re-sprouting capability (Khan and Tripathi 1986, 1989). The ecological significance of these recurrent fires on forest establishment is important. Fires firmly promote few fire-tolerant species that can replace the naturally growing species in an undisturbed environment.

Several studies have been conducted across the globe in the last few decades to understand the effect of fires on vegetation, soil properties, and biomass (Verma and Jayakumar 2012, Whelan 1995). But most of these studies were conducted in the temperate regions. Forest fires are widespread phenomena in Indian forests. Studies suggest that $90 \%$ of vegetation fires in India may be man-made, and annually about 3.73 million ha of forest areas are affected by forest fires (Srivastava and Garg 2013). Tropical 
dry deciduous forests are more vulnerable to forest fire than any other forest across the world (Janzen 1988, Murphy and Lugo 1986). Maximum forest fires in India have been reported in tropical dry deciduous followed by tropical moist deciduous forest and tropical semievergreen forest (FSI 2012). In India, studies on forest fire are majorly focused on monitoring and management of forest fire. Only a few studies have addressed the ecological perspective of a forest fire.

There are very limited studies in India on ecological dynamics of tropical deciduous forests after fire (Kodandapani et al. 2008, 2009, Saha and Howe 2003, Verma and Jayakumar 2015). Few researchers have tried to study forest fire in the Western Ghats, for example, Srivastava et al. (2014) mapped fire-risk areas in Mudumalai Tiger Reserve (MTR) and Mondal and Sukumar (2014) studied characteristic weather pattern associated with fire. Verma et al. (2015) studied the spatial and temporal pattern of forest fire in MTR. Kodandapani et al. (2004, 2008, and 2009) studied fire history, fire return interval, ecological impact of fire, and conservation threats of forest fire in the Western Ghats from 1989 to 2005 with changing fire regime, and they found that species diversity and regeneration initially increases in low fire frequencies and then start decreasing. Similar results were also reported by Verma and Jayakumar (2015) who studied the effect of fire frequencies on tropical dry deciduous forest in MTR. None of these studies have attempted to study the effect of single fire on diversity and regeneration of tree species and how much time these ecosystems take to recover from a single fire event.

The ubiquitous occurrence of fires suggests that fires potentially play a significant role in the management of landscapes. Without a proper understanding of the causes and effects of fire, it is not possible to meet the challenge of shrinking forest resources in the present and the challenge of climate change in the future. The mean fire return interval for the MTR had been increased significantly to 9.28 years (1999-2013) (Verma and Jayakumar 2015) which was 3.3 years in 1989-2002 as reported by Kodandapani et al. (2004). It has been assumed that these forests need more time for recovery with changing fire regime, and it will have an effect on the regeneration and species composition. Hence, the present study is aimed to understand the role of single fire event in the dynamics of tree species diversity, stand structure, and regeneration in a tropical dry deciduous forest of Western Ghats. The main questions are as follows: (1) How is tree diversity affected by a single fire event? (2) How does regeneration vary after different numbers of years since burning? (3) Which species are benefitted by single fire? and (4) How does a single fire affect tree density and stand structure?

\section{Methods}

Study area

Mudumalai Tiger Reserve $\left(11^{\circ} 32^{\prime}\right.$ and $11^{\circ} 43^{\prime} \mathrm{N}$ and $76^{\circ}$ $22^{\prime}$ and $76^{\circ} 45^{\prime} \mathrm{E}$ ) is located in the state of Tamilnadu, India, and is a part of the Nilgiri Biosphere Reserve. It lies at the tri-junction of Kerala, Karnataka, and Tamilnadu (Fig. 1).

The park is contiguous with Bandipur National Park $\left(874 \mathrm{~km}^{2}\right)$, Wayanad Wildlife Sanctuary $\left(344 \mathrm{~km}^{2}\right)$, and Sigur and Singara reserve forests. Its topography is extremely varied and comprises of hills, valleys, ravines, water courses, and swamps. It is spread over an area of $321 \mathrm{~km}^{2}$. Three distinct seasons are recognized in MTR: dry season (January-April), first wet season (May-August), and second wet season (SeptemberDecember) (Dattaraja et al. 2013). Average annual rainfall varies from $721 \mathrm{~mm}$ year $^{-1}$ in the east to $1681 \mathrm{~mm}$ year $^{-1}$ in the west (Dattaraja et al. 2013). The mean temperature ranges from $15.7-28.7{ }^{\circ} \mathrm{C}$ between November and April. Champion and Seth (1968) classified the vegetation type in Mudumalai as southern tropical dry thorn forest, southern tropical dry deciduous forest, southern tropical moist deciduous forest, southern tropical semi-evergreen, moist bamboo brakes, and riparian forest. While vegetation in the eastern part of MTR is open thorny scrub to dry deciduous characterized by a poor and stunted growth, the vegetation in western portion tends to be semi-evergreen. The dry deciduous forest lies in northern portion whereas the vegetation in southern portion is moist deciduous. MTR was dominated by Dalbergia latifolia, Pterocarpus marsupium, and Lagerstroemia microcarpa 150 years ago (Cleghorn, 1861) which is at present dominated by Anogeissus latifolia and Terminalia crenulata (Verma and Jayakumar 2015).

\section{Fire mapping}

Fire frequency maps were prepared by using fire maps of each year from 1999 to 2013. For the period between 2001 and 2012, fire maps available in the Tamilnadu Forest Department were obtained. Fire maps for the year 1999, 2000, and 2013 were prepared using satellite images of Landsat 5 Thematic Mapper acquired on 2 February 1999 and 7 April 1999; Landsat 7 ETM+ acquired on 28 January 2000, 1 April 2000, 17 April 2000, 3 May 2000, and 31 January 2013; and Landsat 8 OLITIRS acquired on 13 April 2013. Spatial resolution of satellite imagery was $30 \mathrm{~m}$. Satellite images for the study area were extracted, geo-corrected, and classified into burned and unburned areas using supervised classification. We used ERDAS Imagine 2011 to analyze the satellite images.

From the fire map, unburned pixels and burned once between 1999 and 2013 were selected. The unburned pixels 


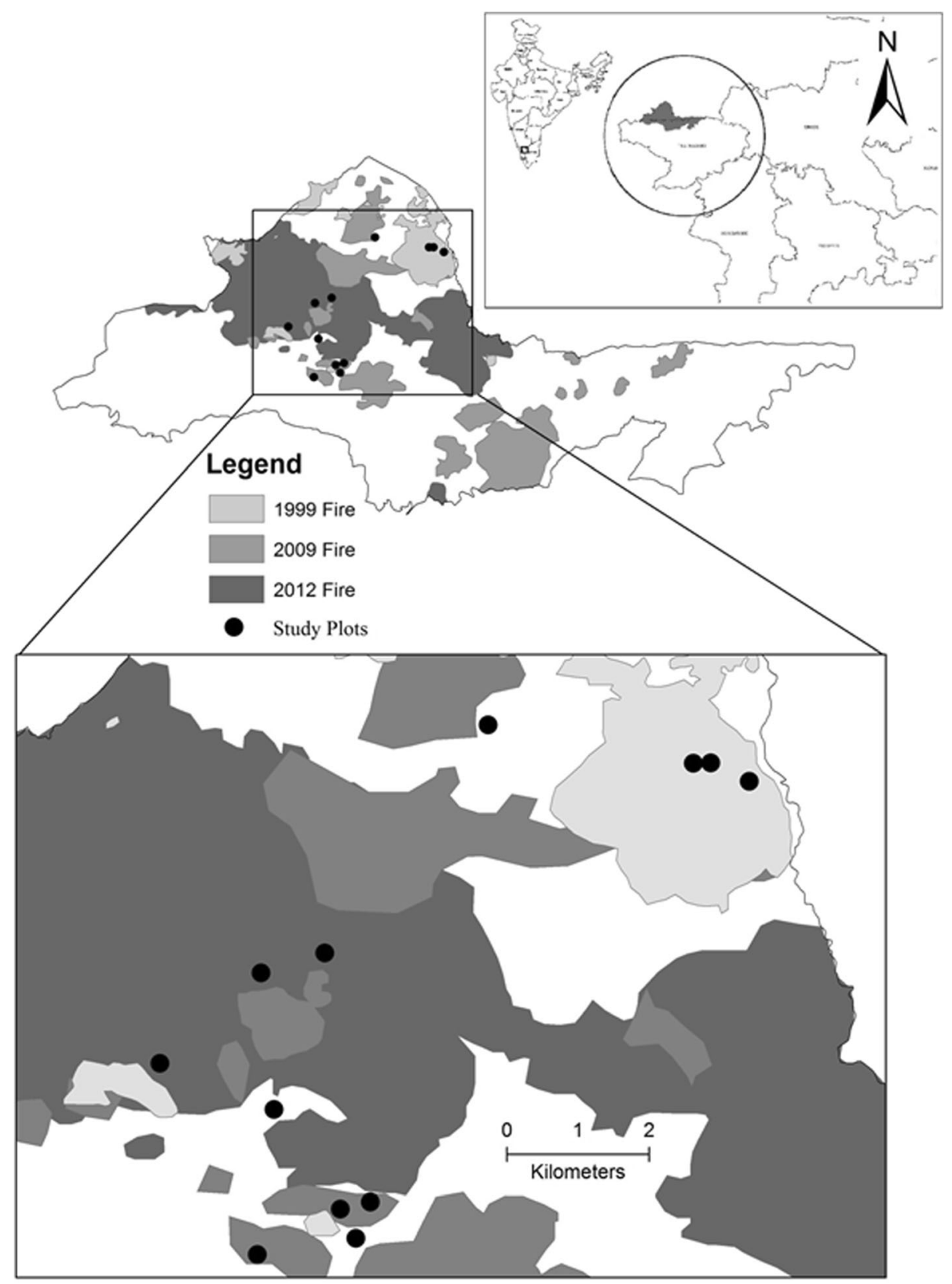

Fig. 1 Location map of Mudumalai Tiger Reserve

were grouped into control (B0), pixels that burned in 2012 were designed as 2-year-old burn (B2), pixels burned in 2009 were labeled as 5-year-old burn (B5), and pixels burned in 1999 were marked as 15-year-old burn (B15).

\section{Field data collection}

This study was conducted in the one-time burned deciduous forest patches which were burned once in 2012 (B2), 2009 (B5), and 1999 (B15), respectively. Three 0.1 ha square plots were laid randomly, independent to each other in all burned and unburned patches, and there were no significant differences within these plots. All woody stems inside the plots were enumerated. For seedlings, four $5 \times 5 \mathrm{~m}$ subplots were laid on the four corners of the 0.1 ha plot. Plot size was constant across all samples. Vegetation data were collected in the month of November and December 2013. All the trees were identified using checklists and flora of Mudumalai (Sharma et al. 1978). Measurements such as collar girth (CG) (for saplings), girth at breast height (GBH) (for trees), and height $(\mathrm{H})$ were recorded for all the woody plants for both living and dead. For seedlings, only number was counted. The 

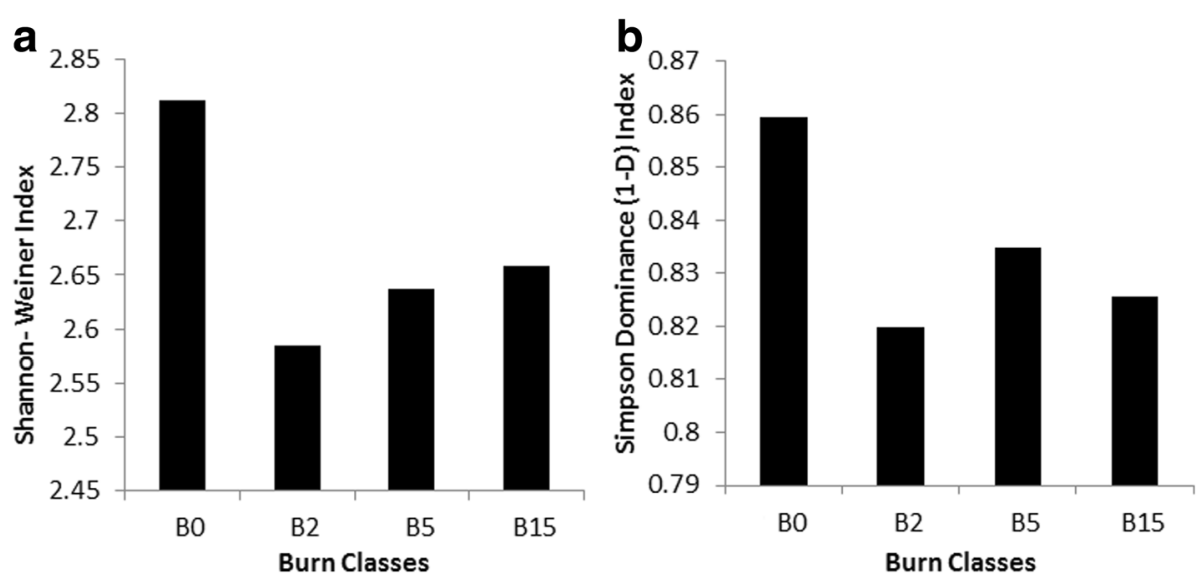

Fig. 2 Shannon-Weiner index (a) and Simpson's dominance index (b) for the stems present in different Burn and control class

seedlings were defined as height less than $50 \mathrm{~cm}$ whereas saplings were defined as height $50-150 \mathrm{~cm}$ and collar girth 1 to $\leq 10 \mathrm{~cm}$. Trees were defined as $>10 \mathrm{~cm} \mathrm{GBH}$.

\section{Data analysis}

The diversity of all living stems was estimated by using the Shannon-Wiener index $\left(H^{\prime}\right)$ and Simpson's dominance index (1-D) (Magurran 2013). The total number of species and species in different growth forms (seedlings, saplings, and trees) were calculated. For each growth form, stem density and basal area data were calculated and subjected to one-way ANOVA to examine significant differences in these variables among fire frequency classes. Means that exhibited differences were compared using Tukey's test with a $5 \%$ probability significance threshold. GBH was converted to dbh (Diameter at breast height). Stem size distribution was analyzed as the total count per size class within fire class to see stand structure. All statistical analyses were performed using IBM SPSS Statistics 20.

\section{Results}

Six fire frequencies were recorded between 1999 and 2013. Only 80.25 ha $(0.25 \%)$ area received six-time fire in 15 years of the study period between 1999 and 2013, whereas 770.40 ha $(2.40 \%)$ burned five times, 2664.30 ha (8.30\%) burned four times, 4494 ha (14\%) burned thrice,
5977.02 ha (18.62\%) burned twice, 8503.29 ha (26.49\%) burned once, and 9601.11 ha (29.91\%) remained unburned. Burned area decreased with increasing fire frequency.

A total of 4129 individuals of tree species were recorded in field surveys, comprising 3474 seedlings, 121 saplings, and 534 trees. The mean density of tree species was 0.34 individual $\mathrm{m}^{-2}$. Totally, 28 species were present in seedlings, 16 species in saplings, and 37 species in tree stage in the study area. Shannon-Weiner index and Simpson dominance index showed that diversity was highest in the control (Fig. 2). Diversity decreases immediately after the fire and then start increasing thereafter but could not reach the level of control even after 15 years. Number of species was also highest in B0 in all stages. The highest basal area was recorded for B0, and the lowest was for 2-year-old burn (Table 1). Stand density was highest for B15 $\left(570 \pm 26.5 \mathrm{ha}^{-1}\right)$ and lowest for B2 $\left(370 \pm 52.9 \mathrm{ha}^{-1}\right)$. Stand density decreased immediately after the fire but increased 5 years after fire (Table 1 ).

Fire significantly affected the stand structure of tree species. The number of stems in smaller size class started increasing after the fire. In the control plot, maximum number of stems were present in $20-30 \mathrm{~cm}$ dbh size class, whereas the number of stems was highest in 0-10 cm dbh size class in B15. Significant changes were observed only in lower size classes $(<20 \mathrm{~cm})$ (Fig. 3).

Table 1 Description of site characteristics: year of burn, species richness, basal area, and stem density

\begin{tabular}{|c|c|c|c|c|c|c|}
\hline \multirow{2}{*}{$\begin{array}{l}\text { Class } \\
\text { code }\end{array}$} & \multirow[t]{2}{*}{ Year of occurrence } & \multirow{2}{*}{$\begin{array}{l}\text { Basal area } \\
\mathrm{m}^{2} \mathrm{ha}^{-1} \\
(\mathrm{SD})\end{array}$} & \multirow{2}{*}{$\begin{array}{l}\text { No. of } \\
\text { stems ha } \\
{ }^{-1} \text { (SD) }\end{array}$} & \multicolumn{3}{|l|}{ Species } \\
\hline & & & & Seedlings & Saplings & Trees \\
\hline BO & Never burned in past 15 years & $36.81(2.19)$ & $407(41.63)$ & 19 & 10 & 23 \\
\hline B2 & 2012 & $24.88(3.25)$ & $370(52.91)$ & 17 & 9 & 18 \\
\hline B5 & 2009 & $29.70(7.21)$ & $463(32.15)$ & 17 & 8 & 19 \\
\hline B15 & 1999 & $25.49(5.85)$ & $570(26.46)$ & 17 & 8 & 18 \\
\hline
\end{tabular}



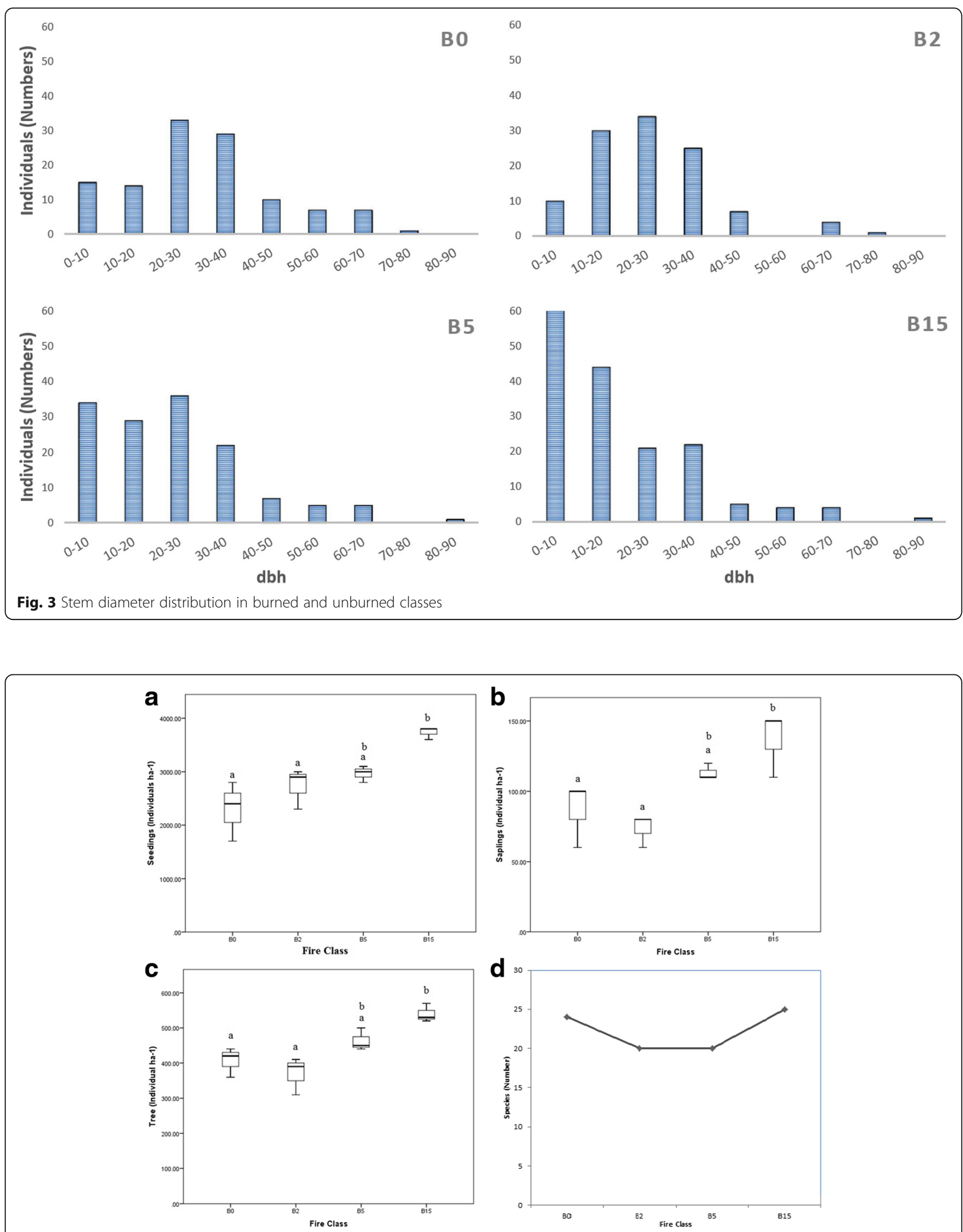

Fig. 4 Box plot of $\mathbf{a}$ seedlings $\mathbf{b}$ saplings $\mathbf{c}$ trees, and $\mathbf{d}$ the relationship between total species regenerating and fire class. Different letters denote significant differences at $p<0.05$ utilizing Tukey test 
Table 2 Abundance (Individuals $\mathrm{ha}^{-1}$ ) of top 10 species of seedlings, saplings, and trees

\begin{tabular}{|c|c|c|c|c|c|c|}
\hline \multicolumn{7}{|c|}{ Seedlings } \\
\hline S.N. & Species name & Family & SBO & SB2 & SB5 & SB15 \\
\hline 1 & Anogeissus latifolia (DC.) Wall. ex Guill \& Perr. & Combretaceae & 270 & 370 & 330 & 470 \\
\hline 2 & Randia dumetorum (Retz.) Poir & Rubiaceae & 170 & 330 & 270 & 330 \\
\hline 3 & Tectona grandis L.f. & Verbenaceae & 200 & 200 & 330 & 330 \\
\hline 4 & Terminalia crenulata (Heyne) Roth & Combretaceae & 230 & 270 & 270 & 270 \\
\hline 5 & Grewia tiliifolia Vahl & Tiliaceae & 200 & 200 & 270 & 330 \\
\hline 6 & Phyllanthus emblica L. & Euphorbiaceae & 130 & 130 & 130 & 470 \\
\hline 7 & Kydia calycina Roxb. & Malvaceae & 70 & 270 & 270 & 70 \\
\hline 8 & Lagerstroemia microcarpa Wight & Lythraceae & 170 & 300 & 200 & $\mathrm{~N} / \mathrm{P}$ \\
\hline 9 & Cassia fistula $\mathrm{L}$. & Caesalpiniaceae & 30 & 170 & 230 & 200 \\
\hline 10 & Shorea roxburghii G. Don & Dipterocarpaceae & 130 & $\mathrm{~N} / \mathrm{P}$ & 130 & 200 \\
\hline \multicolumn{7}{|c|}{ Saplings } \\
\hline 1 & Anogeissus latifolia (DC.) Wall. ex Guill \& Perr. & Combretaceae & 20 & 17 & 33 & 50 \\
\hline 2 & Tectona grandis L.f. & Verbenaceae & 13 & 20 & 40 & 13 \\
\hline 3 & Terminalia crenulata (Heyne) Roth & Combretaceae & 17 & 13 & 20 & 17 \\
\hline 4 & Phyllanthus emblica L. & Euphorbiaceae & 7 & 3 & $N / P$ & 30 \\
\hline 5 & Randia dumetorum (Retz.) Poir & Rubiaceae & 3 & 3 & $\mathrm{~N} / \mathrm{P}$ & 17 \\
\hline 6 & Grewia tiliifolia Vahl & Tiliaceae & 10 & N/P & $\mathrm{N} / \mathrm{P}$ & 3 \\
\hline 7 & Dalbergia latifolia Roxb. & Fabaceae & $\mathrm{N} / \mathrm{P}$ & 7 & 3 & $\mathrm{~N} / \mathrm{P}$ \\
\hline 8 & Cassia fistula $\mathrm{L}$. & Caesalpiniaceae & $\mathrm{N} / \mathrm{P}$ & 3 & 3 & 3 \\
\hline 9 & Terminalia chebula Retz. & Combretaceae & $\mathrm{N} / \mathrm{P}$ & 0 & 7 & $\mathrm{~N} / \mathrm{P}$ \\
\hline 10 & Lagerstroemia microcarpa Wight & Lythraceae & $\mathrm{N} / \mathrm{P}$ & 3 & 3 & $\mathrm{~N} / \mathrm{P}$ \\
\hline \multicolumn{7}{|c|}{ Trees } \\
\hline 1 & Tectona grandis L.f. & Verbenaceae & 97 & 80 & 123 & 77 \\
\hline 2 & Terminalia crenulata (Heyne) Roth & Combretaceae & 67 & 67 & 90 & 107 \\
\hline 3 & Anogeissus latifolia (DC.) Wall. ex Guill \& Perr. & Combretaceae & 43 & 73 & 83 & 70 \\
\hline 4 & Phyllanthus emblica L. & Euphorbiaceae & 20 & 13 & 20 & 140 \\
\hline 5 & Lagerstroemia microcarpa Wight & Lythraceae & 47 & 27 & 20 & $\mathrm{~N} / \mathrm{P}$ \\
\hline 6 & Cassia fistula $\mathrm{L}$. & Caesalpiniaceae & 7 & 17 & 33 & 20 \\
\hline 7 & Randia dumetorum (Retz.) Poir & Rubiaceae & 27 & 17 & 13 & 17 \\
\hline 8 & Grewia tiliifolia Vahl & Tiliaceae & 10 & 7 & 17 & 17 \\
\hline 9 & Radermachera xylocarpa (Roxb.) Roxb. ex K.Schum. & Bignoniaceae & 17 & 7 & 13 & $\mathrm{~N} / \mathrm{P}$ \\
\hline 10 & Dalbergia latifolia Roxb. & Fabaceae & 13 & 10 & 10 & 3 \\
\hline
\end{tabular}

N/P not present

Most abundant species in the group is in bold

Significant differences in the mean stem density of seedlings $(\mathrm{F} 3,8=8.83 ; P=0.006)$ and saplings (F3, $8=8.82 ; P=0.006$ ) were observed among fire classes. Tree population $(\mathrm{F} 3,8=0.259, P=0.853)$ did not show substantial variation among the fire classes. Seedling density (Fig. 4a) increased in all classes after fire, whereas sapling (Fig. 4b) and tree (Fig. 4c) density initially decreased but increased 5 years after fire.

Abundance data showed that in seedlings A. latifolia dominated in all fire classes followed by Randia dumetorum and Tectona grandis (Table 2). For saplings, individuals of A. latifolia, T. grandis, and T. crenulata increased with increasing time after fire (Table 2). In tree stage, T. grandis was most abundant in B0, B2, and B5 whereas A. latifolia and Phyllanthus emblica were most abundant in B15 (Table 2).

\section{Discussion}

Fire used to be extremely rare in tropical forests, leaving ample time for forests to regenerate to pre-fire conditions (Slik et al. 2008). In recent decades, however, tropical forest fires occur more frequently and at larger spatial scales than 
they used to be earlier (Dickson et al. 2006, Slik et al. 2008, Stephens et al. 2015). Annual fires are very common all over MTR. Most of these are low-intensity surface fires (Kodandapani et al. 2008), but their impact on the forest ecosystem is large. These fires are anthropogenic in nature, and the main causes of these fires are poaching, antler collection, grazing, tourism, estates, and settlements in and around the reserve (Srivastava et al. 2014, Verma et al. 2015). The poachers light fire for visibility. The inflammable material continuously cast down by the deciduous trees offers even an accidental spark, the chance of developing into an extensive and devastating fire (Verma et al. 2015).

Results showed that a single fire event can significantly affect diversity and regeneration of trees. Species diversity decreased and dominance increased immediately after fire due to stem mortality in lower size class. After 5 years of fire, diversity was slightly higher but it may take longer time than 15 years to reach the level of control. Post fire decrease in species richness is also reported by Saha and Howe (2003) in dry deciduous forest of Central India. They suggested that fire favors proliferation of root-sprouters, which leads to decrease in diversity.

Single fire event did not show a significant impact on the density of trees and basal area, which suggest that mortality caused by fire would be in lower size classes. Analysis of stand distribution in different girth classes showed variation in lower size classes alone.

The density of seedling and sapling was significantly higher in burned plots and increasing with time. It suggests that single fire event could be beneficial for the regeneration of trees. Increased available nutrient, decrease in pathogen population, breaking in seed dormancy, and opening of mineral soils could be the reason for enhanced number of seedlings and saplings. Our results also supported by the studies of Gould et al. (2002) and Mondal and Sukumar (2015). They have also found increased number of seedlings and sapling in burnt patches compared to unburnt patches.

\section{Conclusions}

It is concluded from this study that even a single fire event has a varying degree of impact on tree species of dry deciduous forest. The single fire has affected stem density significantly, which initially decreases but increases after 5 years. All fire classes (B2, B5, and B15) have recorded with less diversity than control. Maximum impacts of fire were on trees in smaller stem size. The number of seedlings increased after fire, whereas the number of saplings and trees decreased in B2 but increased after 5 years. Further studies are required to understand future responses to post-fire changes and to build a predictive model for different burned forest environments.

\section{Acknowledgements}

We thank the Tamil Nadu Forest Department for granting us permission and providing data to conduct this study at the Mudumalai Tiger Reserve. We acknowledge the support of field assistants and forest staff of Mudumalai Tiger Reserve for their help and cooperation. The first author thank the University Grants Commission, New Delhi for providing the financial support for the Ph.D. research through Junior Research Fellowship (UGC letter No. F. 17-115/98 (SA-I) dated 11 June 2013).

\section{Authors' contributions}

SJ and SV planned the work and did analysis and manuscript preparation. SV and SM Prepared Fire Maps. DS and SV conducted fieldwork. All authors read and approved the final manuscript.

\section{Consent for publication}

Not applicable.

\section{Competing interests}

Authors have no financial and non-financial competing interests.

\section{Publisher's Note}

Springer Nature remains neutral with regard to jurisdictional claims in published maps and institutional affiliations.

Received: 18 June 2017 Accepted: 6 August 2017

Published online: 14 September 2017

\section{References}

Balch JK, Massad TJ, Brando PM, Nepstad DC, Curran LM (2013) Effects of highfrequency under storey fires on woody plant regeneration in southeastern Amazonian forests. Phil Trans R Soc B 368:20120157 http://dx.doi.org/10. 1098/rstb.2012.0157

Champion HG, Seth SK (1968) Revised forest types of India. Government of India, New Delhi, p 404

Cleghorn HFC (1861) The forests and gardens of south India. WH Allen \& Company

Danthu P, Ndongo M, Diaou M, Thiam O, Sarr A, Dedhiou B, Vall AOM (2003) Impact of bush fire on germination of some West African acacias. Forest Ecol Manag 173:1-10

Dattaraja HS, Pulla S, Mondal N, Suresh HS, Bharanaiah CM, Sukumar R (2013) Spatial interpolation of rainfall for Mudumalai Wildlife Sanctuary and Tiger Reserve, Tamil Nadu. India, CES Technical Report

De Luis M, Raventos J, González-Hidalgo JC (2005) Factors controlling seedling germination after fire in Mediterranean gorse shrublands. Implications for fire prescription J Environ Manage 76:159-166

Dickson BG, Prather JW, Xu Y et al (2006) Mapping the probability of large fire occurrence in northern Arizona, USA. Landsc Ecol 21:747. doi:10.1007/s10980005-5475-x

FSI (2012) Vulnerability of India's forests to fire. Forest Survey of India, Ministry of Environment and Forest, Government of India

Gould KA, Fredericksen TS, Morales F, Kennard D, Putz FE, Mostacedo B, Toledo M (2002) Post-fire tree regeneration in lowland Bolivia: implications for fire management. Forest ecol Manag, 15;165 (1):225-34

Janzen DH (1988) Tropical dry forests. Biodiversitas 15:538

Keane RE, Ryan KC, Veblen TT, Allen CD, Logan JA, Hawkes B (2002) The cascading effects of fire exclusion in Rocky Mountain ecosystems. Rocky Mountain futures: an ecological perspective:133-152

Kennard DK, Gould K, Putz FE, Fredericksen TS, Morales F (2002) Effect of disturbance intensity on regeneration mechanisms in a tropical dry forest. Forest Ecol Manag 162(2):197-208

Khan ML, Tripathi RS (1986) Tree regeneration in a disturbed sub-tropical wet hill forest of north-east India: effect of stump diameter and height on sprouting of four tree species. Forest Ecol Manag 17(2-3):199-209

Khan ML, Tripathi RS (1989) Effects of stump diameter, stump height and sprout density on the sprout growth of four tree species in burnt and unburnt forest plots. Acta Oecol 10(4):303-316

Kodandapani N, Cochrane MA, Sukumar R (2004) Conservation threat of increasing fire frequencies in the Western Ghats, India. Conserv Biol 18(6):1553-1561

Kodandapani N, Cochrane MA, Sukumar R (2008) A comparative analysis of spatial, temporal, and ecological characteristics of forest fires in seasonally dry tropical ecosystems in the Western Ghats, India. Forest Ecol Manag 256(4):607-617 
Kodandapani N, Cochrane MA, Sukumar R (2009) Forest fire regimes and their ecological effects in seasonally dry tropical ecosystems in the Western Ghats, India. In: Tropical Fire ecology. Springer Berlin, Heidelberg, pp 335-354

Magurran AE (2013) Ecological diversity and its measurement. Springer Science \& Business Media. Springer Netherlands. doi:10.1007/978-94-015-7358-0

Mondal N, Sukumar R (2014) Characterising weather patterns associated with fire in a seasonally dry tropical forest in southern India. Int J Wildland Fire 23(2):196-201

Mondal N, Sukumar R (2015) Regeneration of juvenile woody plants after fire in a seasonally dry tropical forest of Southern India. Biotrop 47(3):330-338

Murphy PG, Lugo AE (1986) Ecology of tropical dry forest. Annu rev of eco and syst $17(1): 67-88$

Saha S, Howe HF (2003) Species composition and fire in a dry deciduous forest. Ecology 84(12):3118-3123

Sharma BD, Shetty BV, Vivekananthan K, Rathakrishnan NC (1978) Flora of Mudumalai wildlife sanctuary, Tamil Nadu. J Bom Nat Hist Soc 75(1):13-42

Slik JF, Bernard CS, Van Beek M, Breman FC, Eichhorn KA (2008) Tree diversity, composition, forest structure and aboveground biomass dynamics after single and repeated fire in a Bornean rain forest. Oecologia 158(3):579-588

Srivastava P, Garg A (2013) Emissions from Forest Fires in India-as assessment based on MODIS Fire and Global land cover products. Clim Cha and Enviro Sust 1(2):138-144

Srivastava SK, Saran S, De By RA, Dadhwal VK (2014) A geo-information system approach for forest fire likelihood based on causative and anti-causative factors. Int J Geogr Inf Sci 28(3):427-454

Stephens SL, North MP, Collins BM. (2015) Large wildfires in forests: what can be done? American Institute of Biological Sciences, action bioscience: http:// www.actionbioscience.org/environment/large_wildfires_in_forests_what_ can_be_done.html\#

Syaufina L, Nuruddin AA (2011) Impacts of fire on South East Asia tropical forests biodiversity: a review. Asian J Plant Sciences 10(4):238-244

Verma S, Jayakumar S (2012) Impact of forest fire on physical, chemical and biological properties of soil: a review. Proc of the Int Aca of Eco and Env Sci 2(3):168-176

Verma S, Jayakumar S (2015) Post-fire regeneration dynamics of tree species in a tropical dry deciduous forest, Western Ghats, India. Forest Ecol Manag 341:75-82

Verma S, Vashum KT, Sathya M, Jayakumar S (2015) Monitoring changes in Forest Fire Pattern in Mudumalai Tiger Reserve, Western Ghats India, using Remote Sensing and GIS. GJSFR-H Retrieved from https://journalofscience.org/index. php/GJSFR/article/view/1663

Walters M, Midgley JJ, Somers MJ (2004) Effects of fire and fire intensity on the germination and establishment of Acacia karroo, Acacia nilotica, Acacia luederitzii and Dichrostachys cinerea in the field. BMC Ecol 4(1):1

Whelan RJ (1995) The ecology of fire. Cambridge University Press

\section{Submit your manuscript to a SpringerOpen ${ }^{\circ}$ journal and benefit from:}

- Convenient online submission

- Rigorous peer review

Open access: articles freely available online

- High visibility within the field

Retaining the copyright to your article

Submit your next manuscript at $>$ springeropen.com 